\title{
Management of women with abnormal cervical smears: supplement to Terminology in Gynaecological Cytopathology
}

\author{
D M D EVANS, ${ }^{*}$ E A HUDSON, $\dagger$ C L BROWN,$\ddagger$ M M BODDINGTON,§ H E HUGHES, \\ E F D MACKENZIE**
}

From the Departments of Histopathology, ${ }^{*}$ Llandough Hospital, Penarth, Wales, and $\dagger$ Northwick Park Hospital, Harrow, Middlesex, the $\ddagger$ Institute of Pathology, The London Hospital, and the Departments of Cytopathology, §Royal Berkshire Hospital, Reading, ๆGlasgow Royal Infirmary, and **Southmead General Hospital, Bristol

SUMMARY Recommendations are made for the management of patients with abnormal cervical smears. Colposcopic examination is indicated for persistent mild and moderate dyskaryosis, as well as for severe dyskaryosis.

Prevention of cervical cancer by cytological screening depends on detection of dyskaryotic cells obtained from the surface of cervical epithelium. Careful characterisation of the cellular abnormalities can be expected to permit cytological classification that correlates in many cases with the histological classification of cervical intraepithelial neoplasia (CIN) grades I, II, or III.

The management of patients with abnormal smears is based on the limited information available about the behaviour of CIN. It is known that patients with severe dyskaryosis (suggesting CIN3) have a risk of progression to invasive cancer, sufficiently high and immediate to merit early biopsy for histological confirmation and treatment. ${ }^{1-2}$ The difficulty of reliably excluding an invasive carcinoma in such cases makes early biopsy a priority. The behaviour of mild and moderate dyskaryosis is less certain, but there is no doubt that a number of these abnormalities will progress to invasive cancer if untreated. It is not possible at present to predict the behaviour from the morphological appearances ${ }^{3}$; therefore follow up or biopsy is essential.

The development of colposcopy and ablative treatment for suitable lesions permits a more generous referral policy than when cone biopsy was the only procedure for both diagnosis and treatment. It is reasonable, therefore, to refer for colposcopy patients whose smears persistently show dyskaryosis. Until there is a reliable means of distinguishing the premalignant mild dyskaryosis (and the changes associ-

Accepted for publication 2 December 1986 ated with human papilloma virus infection) from the mild dyskaryosis which will regress, all patients with persistent mild abnormalities should be assessed by colposcopy to avoid underestimations that may occur in cytological screening. ${ }^{4}$ As patients with mild dyskaryosis outnumber those with severe dyskaryosis three to four times and a proportion can be expected to return to normal spontaneously, follow up by cytology alone may at present be necessary if colposcopy services are limited. Such a policy might carry a small risk to the patient.

If the dyskaryosis on the first smear is less than severe a repeat smear should be taken within three months as sampling errors can occur. Endocervical cells in a smear provide some indication that it is a good sample but their presence is not proof that the whole circumference of the squamocolumnar junction has been scraped. The absence of endocervical cells does not necessarily mean that the smear has been badly taken, although there is no proof that it is a good sample. Those taking smears should use their discretion about retaking the smear or repeating it after a shorter interval than otherwise recommended.

Invasive cancers are more likely to give a false negative smear result than is CIN. This may be due to excessive blood and inflammatory cells replacing epithelial cells and giving an unsatisfactory smear or there may be few abnormal cells from an invasive lesion and they may be difficult to interpret. A cervix which looks suspicious therefore should be biopsied even if the smear is negative.

Patients who have had dyskaryosis, whether treated or not, remain at higher risk of invasive 
Table Summary of recommendations for management and follow up of women with abnormal cervical smears

\begin{tabular}{ll}
\hline Cytology & Management \\
\hline $\begin{array}{l}\text { Inadequate or unsuitable } \\
\text { Negative* }\end{array}$ & $\begin{array}{l}\text { Repeat smear soon } \\
\text { Routine recall according to } \\
\text { screening policy for Well Women }\end{array}$ \\
$\begin{array}{l}\text { Koilocytosis and other } \\
\text { warty changes } \\
\text { Borderline changes } \\
\text { (severe inflammatory/ } \\
\text { mild dyskaryosis) } \\
\text { Mild dyskaryosis }\end{array}$ & $\begin{array}{l}\text { Repeat the smear in 3 months and } \\
\text { then manage according to the result } \\
\text { Persisting abnormalities are an } \\
\text { indication for colposcopy }\end{array}$ \\
Moderate dyskaryosis & $\begin{array}{l}\text { Refer for colposcopy if confirmed in } \\
\text { a second smear } \\
\text { Severe dyskaryosis }\end{array}$ \\
Refer for colposcopy
\end{tabular}

All dyskaryosis requires careful follow up, even after treatment.

*If there is strong clinical suspicion of cervical malignancy the patient should be referred for biopsy even if the smear is negative.

carcinoma than those who have not. ${ }^{5-6}$ Until more evidence of the duration of this risk is available we advise that regular smears should be taken after the cytology has returned to normal.
The table summarises the recommendations for management and follow up of women with abnormal cervical smears. It is a general guide which may require modification for individual patients.

\section{References}

1 Walton RJ. Canadian Task Force Report. Cervical cancer screening programs. Can Med Assoc J 1976;114:1003-33.

2 Kinlen LJ, Spriggs AI. Women with positive cervical smears but without surgical intervention. Lancet 1978;ii:463-5.

3 Buckley $\mathrm{CH}$, Butler EB, Fox H. Cervical intraepithelial neoplasia. $J$ Clin Pathol 1982;35:1-13.

4 Soutter WP, Wisdom S, Brough AK, Monaghan JM. Should patients with mild atypia in a cervical smear be referred for cilposcopy? Br J Obstet Gynaecol 1986;93:70-4.

5 Macgregor JE. Preclinical neoplasia of the cervix. In: Jordan JA, Sharp F, Singer A, eds. Proceedings of the ninth study group of the Royal College of Obstetricians and Gynaecologists. London: Royal College of Obstetricians and Gynaecologists, 1982: 95-110.

6 Burghardt E, Holzer E. Treatment of carcinoma in situ: evaluation of 1609 cases. Obstet Gynecol 1980;55:539-45.

Requests for reprints to: Dr Elizabeth A Hudson, Consultant Cytopthologist, Department of Histopathology, Northwick Park Hospital, Harrow, Middlesex HAl 3UJ, England. 